MAHLER'S FORGOTTEN CONDUCTOR 



\section{Mahler's Forgotten Conductor}

Heinz Unger and His Search for Jewish Meaning, 1895-1965

HERNAN TESLER-MABÉ

UNIVERSITY OF TORONTO PRESS

Toronto Buffalo London 
(C) University of Toronto Press 2020

Toronto Buffalo London

utorontopress.com

Printed in Canada

ISBN 978-1-4875-0516-5 (cloth) ISBN 978-1-4875-3167-6 (EPUB)

ISBN 978-1-4875-3166-9 (PDF)

\section{Library and Archives Canada Cataloguing in Publication}

Title: Mahler's forgotten conductor : Heinz Unger and his search for Jewish meaning, 1895-1965 / Herman Tesler-Mabé

Names: Tesler-Mabé, Hernan, author.

Description: Includes bibliographical references.

Identifiers: Canadiana (print) 2019020270X | Canadiana (ebook) 20190203358 | ISBN 9781487505165 (cloth) | ISBN 9781487531676 (EPUB) | ISBN 9781487531669 (PDF)

Subjects: LCSH: Unger, Heinz, 1895-1965. | LCSH: Conductors (Music) Canada - Biography. | LCSH: Conductors (Music) - Germany - Biography. |

LCSH: Jewish musicians - Canada. | LCSH: Jews - Identity.

Classification: LCC ML422 U54 T47 2020 | DDC 784.2092 - dc23

University of Toronto Press acknowledges the financial assistance to its publishing program of the Canada Council for the Arts and the Ontario Arts Council, an Ontario government agency.

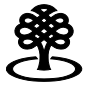

\section{Canada Council} for the Arts

\section{Conseil des Arts}

du Canada

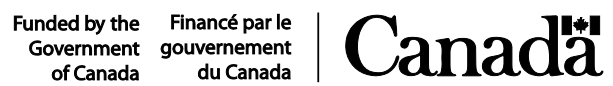

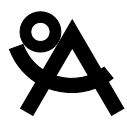
ONTARIO ARTS COUNCIL CONSEIL DES ARTS DE L'ONTARIO

an Ontarlo government agency an Ontarlo government agency
un organlsme du gouvernement de l'Ontarlo

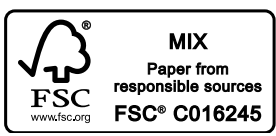


Dedicated to my father Eduardo, who passed away too soon to read this book, and to my $\operatorname{dog}$ Murray, who lay at my feet until it was done. 
